\title{
Focal adhesion kinase in the brain: novel subcellular localization and specific regulation by Fyn tyrosine kinase in mutant mice
}

\author{
Seth G.N. Grant, ${ }^{1-3}$ Kevin A. Karl, ${ }^{2}$ Michael A. Kiebler, ${ }^{2}$ and Eric R. Kandel ${ }^{2}$ \\ ${ }^{1}$ Center for Genome Research \& Centre for Neuroscience, University of Edinburgh, Edinburgh EH9-3JQ UK; ${ }^{2}$ Center for \\ Neurobiology and Behavior, Howard Hughes Medical Institute, Columbia University, New York, New York 10032
}

\begin{abstract}
Signaling by tyrosine kinases is required for the induction of synaptic plasticity in the central nervous system. Comparison of $f y n$, src, yes, and $a b l$ nonreceptor tyrosine kinase mutant mice shows a specific requirement for Fyn in the induction of long-term potentiation at CA1 synapses in the hippocampus. To identify components of a Fyn-dependent pathway that may be involved with hippocampus function we examined tyrosine-phosphorylated proteins in kinase mutant mice. We found that nine proteins were hypophosphorylated specifically in fyn mutants. One of the hypophosphorylated proteins was focal adhesion tyrosine kinase (FAK). FAK also showed reduced activity in immunocomplex kinase assays only in fyn mutants. FAK is expressed at very high levels in the brain but in contrast to non-neural cells, FAK was not restricted to focal adhesion contacts. FAK was found in axons, dendrites, and the intermediate filament cytoskeleton of astrocytes. Brain extracts from the mutants also show specific patterns of compensatory changes in the activity of the remaining Src family kinases. Tyrosine phosphorylation is a critical regulator of FAK, and impairments in FAK signal transduction in fyn mutants may contribute to the mutant neural phenotype.
\end{abstract}

[Key Words: FAK; Fyn tyrosine kinase; mutant mice; tyrosine phosphorylation; long-term potentiation; learning and memory]

Received April 19, 1995; revised version accepted June 23, 1995.

The storage and recall of learned information is thought to reflect modifications in the strength of specific synaptic connections in neural circuits of the brain. The complexity of the brain has impeded the definition of the molecular pathways involved with the modulation of synaptic strength. The biochemical analysis of mice carrying mutations in defined genes, however, provides a new and promising approach to the dissection of these signaling cascades. Gene targeting has been used recently to study the role of individual genes in controlling synaptic strength in the hippocampus and memory storage in the intact animal (Grant et al. 1992; Silva et al. 1992a,b; Abeliovich et al. 1993a,b; Rosahl et al. 1993; Aiba et al. 1994; Bourtchuladze et al. 1994; Conquet et al. 1994; Sakimura et al. 1995; Wu et al. 1995). Mutations in six genes encoding protein kinases have implicated Fyn (Grant et al. 1992), $\alpha-\mathrm{Ca}^{2+} /$ calmodulin-dependent kinase II (Silva et al. 1992a), and protein kinase C- $\gamma$ (PKC- $\gamma$ (Abeliovich et al. 1993a) but not Src, Yes, or $\mathrm{Abl}$ in the control of synaptic strength. The nonreceptor tyrosine kinases lend themselves particularly well to a

${ }^{3}$ Corresponding author. combined biochemical and genetic analysis of signaling pathways involved in synaptic plasticity, as they are closely related, are expressed at similar levels and locations in the brain, and share common structural and regulatory features (for review, see Parsons and Weber 1989; Cooper 1990; Bolen et al. 1992; Cooper and Howell 1993; Maness 1992; Sudol et al. 1993).

Pharmacological inhibitors of protein tyrosine kinases first showed these kinases to be required for the induction of long-term potentiation (LTP) (O'Dell et al. 1991), a form of synaptic plasticity in the hippocampus (for review, see Bliss and Collingridge 1993). The inhibitors showed that tyrosine kinase activity was required in the postsynaptic cell during the induction of LTP /O'Dell et al. 1991). To identify the specific tyrosine kinase required for LTP, we examined four separate nonreceptor tyrosine kinases-Fyn, Src, Yes, and Abl-using mice harboring mutations in their respective genes (Grant et al. 1992). We found that only fyn mutant mice had an impairment in the induction of LTP. The fyn mutants also showed impairments in hippocampus architecture, spatial learning, and in the induction of kindling, another form of long-term plasticity in the amygdala (Cain et al. 1995). The other tyrosine kinase mutants had nor- 
mal hippocampal synaptic phenotypes, indicating a surprising specificity in the neural functions of these kinases.

Why do only fyn and not src or yes mutants show a readily detectable synaptic phenotype? In $T$ cells, Fyn has a well-defined role in signaling from the T-cell receptor (for review, see Bolen et al. 1991; Rudd et al. 1993 ; Chan et al. 1994/. Here, a striking specificity for Fyn is evident. Fyn can interact with the $\zeta$ chain of the T-cell receptor, whereas Src and Lck cannot (Gauen et al. 1992). Not surprisingly, signaling in this pathway is defective in fyn mutant mice (Appleby et al. 1992; Stein et al. 1992). Are there also unique signaling pathways in the brain for Fyn? Such a pathway seems likely, as the brain expresses a structurally distinct isoform of Fyn that has a different catalytic kinase domain and $\mathrm{SH} 2$ domain to the T-cell isoform (Cooke and Perlmutter 1989; Davidson et al. 1994). Studies of cell-adhesion molecules suggest that N-CAM and L-MAG may signal via Fyn during the development of the central nervous system (Beggs et al. 1994; Umemori et al. 1994). The set of Src family kinase mutants provides a unique opportunity to identify components of a Fyn-dependent pathway in the mature nervous system.

We have compared the molecular phenotypes of fyn, src, and yes mutants and addressed three questions. (1) What are the molecular defects in the fyn mutants, and how do they compare to those of src and yes mutants? (2) Are there tyrosine phosphorylated proteins that are specifically regulated by Fyn, and do they provide clues to the subsequent signaling steps in which Fyn participates? (3) Why do mutations in src and yes fail to show a synaptic phenotype? Do other Src family kinases show compensation that masks a phenotype?

We find that in the brain, loss of Fyn leads to a reduction in tyrosine phosphorylation of multiple proteins. In contrast, loss of Src or Yes has no detectable effects on the pattern of tyrosine phosphorylation suggesting that Fyn may be more important in synaptic plasticity than Src or Yes because the function of Fyn cannot be replaced by another kinase. Focal adhesion kinase (FAK) was found to be specifically regulated by Fyn in the brain, as FAK was hypophosphorylated only in fyn and not in src or yes mutants. The hypophosphorylation of FAK was associated with a reduced activity in immunocomplex kinase assays in fyn mutants. Tyrosine phosphorylation and activity of FAK is a key regulatory event and is required for coupling receptors to downstream components of signal transduction pathways (Chen and Guan 1994; Schlaepfer et al. 1994). Studies in fibroblasts have identified a specific domain within FAK that is necessary for its subcellular localization to focal adhesion contacts (Hildebrand et al. 1993). We find that FAK is not restricted to focal adhesion contacts in astroglia and is distributed in axons and dendrites of neurons. These findings suggest that FAK is a component of a Fyn-dependent signaling pathway in the brain and may have novel neural functions that contribute to the defects in synaptic plasticity in fyn mutants.

\section{Results \\ Reduced tyrosine phosphorylation in fyn but not src or yes mutant brains}

As the fyn mutant neural phenotype may result from reduced tyrosine phosphorylation of specific proteins, we first examined the level of tyrosine-phosphorylated proteins from wild-type and $f y n$, src, and yes mutant forebrains in protein extracts. Protein extracts $11 \%$ digitonin) were separated by SDS-PAGE and transferred to membranes that were then probed with antiphosphotyrosine antibodies (RC20). In extracts from fyn mutants, multiple proteins lapproximately 192, 167, 125, 96, 94, $68,62,59$, and $48 \mathrm{kD}$ ) were significantly less phosphorylated (Fig. 1A,B). In contrast, extracts from src and yes mutants did not show this decrease in phosphorylation.

To determine whether this reduction in tyrosine phosphorylation was attributable to hypophosphorylation or to reduced levels of the individual proteins, we next identified one of these proteins. An insight into the identify of the $125-\mathrm{kD}$ protein was provided by an immunocomplex kinase assay using antiphosphotyrosine antibodies. Following immunoprecipitation with antiphosphotyrosine antibodies (mAb 4Gl0) the complex of tyrosine-phosphorylated proteins, antibodies, and protein G-Sepharose was phosphorylated in vitro by addition of ATP (Kypta et al. 1990; Clarke and Brugge 1993). In fyn mutant extracts (Fig. $1 \mathrm{C}$ ) we observed a significant reduction in the phosphorylation of a major phosphoprotein (ppl25 kD). Phosphorylation of ppl25 was resistant to alkali hydrolysis (Fig. 1C), indicating that it was phosphorylated on tyrosine residues. This protein was similar to a $125-\mathrm{kD}$ tyrosine phosphoprotein described in fibroblasts that were transformed by Src tyrosine kinase (Kanner et al. 1990). In fibroblasts, ppl25 was found to be a tyrosine kinase with novel structural features and has been localized to focal cell adhesions. Thus, it was named FAK (Schaller et al. 1992).

\section{Identification of brain pp125 as FAK}

The following criteria suggest that the pp125 that we have detected in the brain is FAK. First, pp125 isolated by parallel immunocomplex kinase assays with antiphosphotyrosine (mAb 4Gl0) or anti-FAK antibodies (mAb 2A7) comigrated on SDS-polyacrylamide gels (Fig. 2A). Second, similar peptide maps were obtained following digestion with V8-protease of pp125 immunoprecipitated with antiphosphotyrosine or FAK antibodies (Fig. 2B). Third, immunodepleting the extract with FAK antibodies prior to immune complex kinase assays with antiphosphotyrosine antibodies removed ppl25 almost quantitatively (Fig. 2C). These data strongly suggest that pp125 observed in antiphosphotyrosine immunocomplex kinase assays from brain extracts was FAK.

\section{FAK phosphorylation and immunocomplex kinase activity is reduced in the brain of fyn mutants}

We next asked whether FAK was hypophosphorylated in 

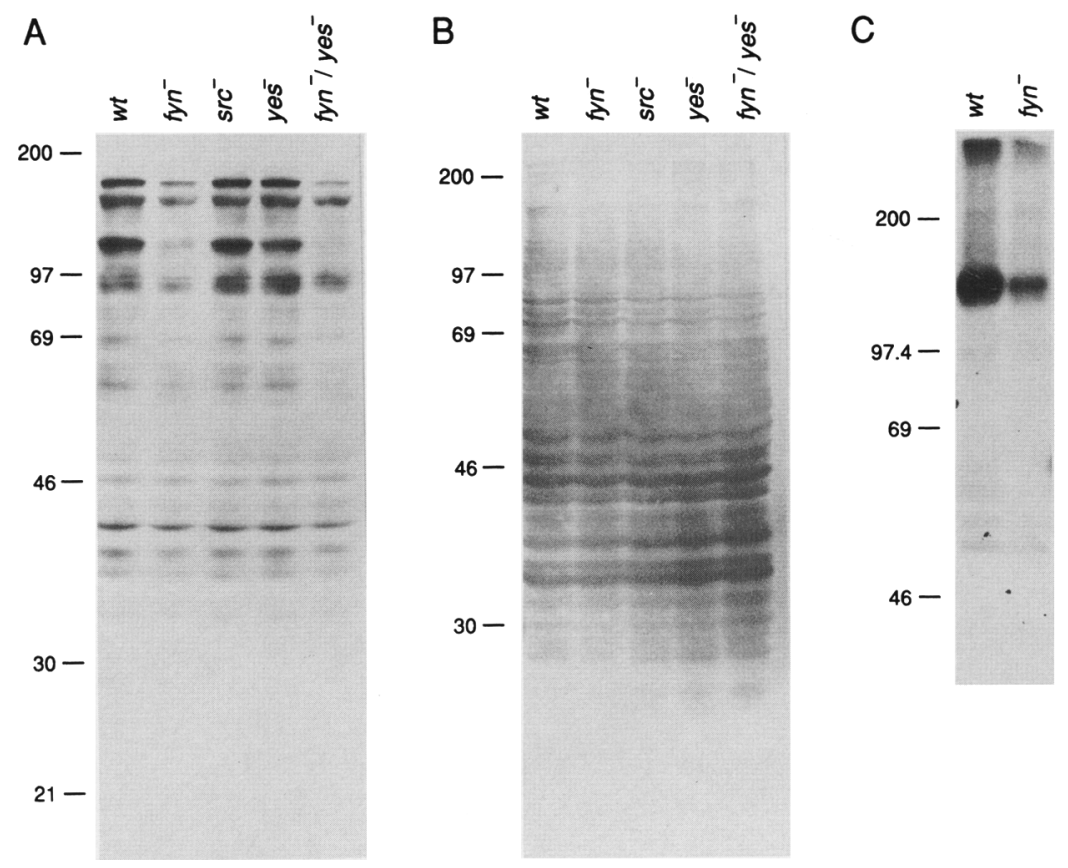

Figure 1. Tyrosine phosphorylation of proteins is reduced in brain extracts of fyn mutant mice. (A) Immunolabeling of brain extracts with antiphosphotyrosine antibodies shows reduced tyrosine-phosphorylation in fyn mutants. Protein phosphorylation in extracts from src and yes mutants was similar to wild type. Extracts from fyn/ yes double mutants showed a similar phosphorylation pattern to fyn mutants. Fresh forebrains from wild-type (wt) or mutant mice (mutant genes as indicated) were lysed in digitonin buffer as described in Materials and methods. Aliquots (75 $\mu \mathrm{g}$ of protein) from each extract were separated on a SDS-polyacrylamide gel ( $10 \%$ acrylamide) and transferred onto a PVDF membrane (used for immunolabeling), backed up by a nitrocellulose membrane (used for protein staining as shown in $B$ ). Immunolabeling was performed with monoclonal antibodies raised against phosphotyrosine residues (RC20, Transduction Labs). Bound antibodies were visualized with the ECL Detection System (Amersham). (B) Protein stain of $A$. The second membrane (nitrocellulose) of the same immunoblot in $A$ was stained /Gold Blot Stain, Integrated Separation Systems) to verify equal protein loading in all lanes. $(C)$ Immunoprecipitation with antiphosphotyrosine antibodies followed by an immunocomplex kinase assay showed a reduced tyrosine phosphorylation of a predominant $125-\mathrm{kD}$ protein in fyn mutant compared to wild-type extracts. Aliquots (150 $\mu \mathrm{g}$ of protein) from brain extracts (1\% digitonin) of either wild-type or fyn mutant mice were subjected to immunoprecipitation with antiphosphotyrosine antibodies (mAb 4G10). The protein G-agarose beads carrying the bound immunocomplexes were then incubated with $\left[\gamma^{32} \mathrm{P} \mid \mathrm{ATP}\left(3 \mathrm{~min}, 25^{\circ} \mathrm{C}\right)\right.$. The kinase reaction was stopped with $20 \mathrm{mM}$ EDTA, and bound proteins were dissociated from the beads by heating $\left(5 \mathrm{~min}, 95^{\circ} \mathrm{C}\right)$ in sample buffer and subjected to SDS-PAGE (8\% acrylamide). Polyacrylamide gels were fixed, incubated in $1 \mathrm{M} \mathrm{KOH}\left(2 \mathrm{hr}, 55^{\circ} \mathrm{C}\right)$ to hydrolyze phosphorylation on serine/threonine residues and dried for autoradiography. (fyn, src, yes, fyn/yes) Forebrain protein extracts of the indicated mutant. Numbers at left indicate molecular masses in $\mathrm{kD}$ (Rainbow markers, Amersham).

extracts from fyn mutants. FAK was immunoprecipitated from wild-type, fyn, src, and yes mutant extracts, separated by SDS-PAGE, and transferred to membranes for Western blotting. The membrane was first probed with antiphosphotyrosine antibodies (RC20) (Fig. 3A), stripped, and reprobed with FAK-specific antiserum (BC3) (Fig. 3B). These data show that the level of FAK tyrosine phosphorylation was reduced in fyn mutants compared to src and yes mutants and wild-type extracts.

In other physiological contexts the basal level of FAK tyrosine phosphorylation correlates directly with its kinase activity in immunocomplex kinase assays /Guan and Shalloway 1992; Lipfert et al. 1992; Vuori and Rhuoslahti 1993). We therefore next examined the activity of FAK from fyn mutants in autophosphorylation and substrate phosphorylation assays, by immunoprecipitating FAK and performing immunocomplex kinase assays. Both autophosphorylation (Fig. $3 \mathrm{C}$ ) and substrate phosphorylation (data not shown) activities were diminished by $50 \%$ in fyn mutant brains. The reduced kinase activity may reflect a reduction in the specific activity of FAK or a FAK-associated kinase. Interestingly, an unidentified $57-\mathrm{kD}$ protein that is associated with FAK shows the same reduction of tyrosine phosphorylation in fyn mutants (Fig. 3C). Since the 57-kD band was seen in extracts from fyn, src, and yes mutants (Fig. 3C), it is unlikely to be $\mathrm{p} 59^{\mathrm{Fyn}}, \mathrm{p} 61^{\mathrm{Src}}$, or $\mathrm{p} 62^{\mathrm{Yes}}$ and it is also different from either $550^{\text {Csk }}$ or immunoglobulin heavy chains used in the immunocomplex kinase assay. Therefore in fyn mutants there is an overall reduction in FAK tyrosine phosphorylation and a reduction in kinase activity of the FAK immunocomplex.

\section{FAK expression in the brain}

Although Northern blots show that FAK mRNA is expressed in the brain (Hanks et al. 1992; Andre and Becker-Andre 1993) and studies on NIH-3T3 cells indicate FAK phosphorylation can be stimulated by neurotransmitters $(\mathrm{ml}$ muscarinic acetylcholine receptor; Gutkind and Robbins 1992) and neuropeptides (bombesin, endothelin, and vasopressin; Zachary et al. 1992), little is known about the expression of the FAK protein or its localization within the nervous system (Polte et al. 1994). To address this issue and obtain some insight into the role of FAK in the brain, we first compared the protein levels of Fyn and FAK in different tissues. Tissue extracts were subjected to immunocomplex kinase assays (Fig. 4A) or immunoblotted (data not shown) with FAK antibodies or Fyn antiserum. These data showed that FAK protein is highly expressed in the brain like that of Fyn. A similar tissue distribution of Fyn expres- 
Figure 2. The tyrosine-phosphorylated pp125 in fyn mutant extracts is FAK. $(A)$ Tyrosine-phosphorylated FAK and ppl25 comigrate on SDS-polyacrylamide gels. Aliquots (150 $\mu \mathrm{g}$ of protein) from brain extracts of wild-type mice were subjected to immunoprecipitation with monoclonal antibodies raised against FAK (mAb 2A7) or antiphosphotyrosine residues (mAb 4Gl0). Immunocomplex kinase assays, SDSPAGE, and visualization were then performed as described for Fig. 1C. (FAK) Immunoprecipitation with anti-FAK antibodies; (ptyr) immunoprecipitation with antiphosphotyrosine antibodies. $(B)$ Digestion of tyrosine-phosphorylated FAK and pp125 with V8-protease reveals very similar fragmentation pattems. Aliquots $\$ 150$ $\mu g$ of protein) from brain extracts of wildtype mice were subjected to immunoprecipitation, immunocomplex kinase assays, and SDS-PAGE as described for $A . \gamma^{32} \mathrm{P}$ labeled FAK or ppl25 (as seen in $A$ ) was excised from the SDS-polyacrylamide gel, rehydrated, and loaded into three wells of a second SDS-polyacrylamide gel $112.5 \%$ acrylamide). V8-protease (S. aureus; $0,0.1$,

$A$

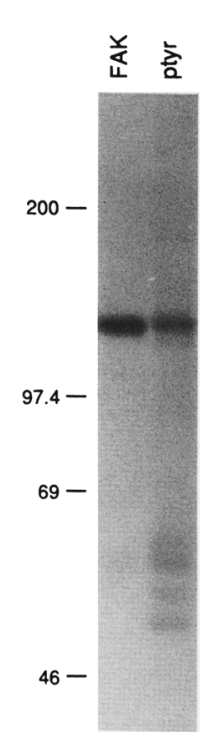

B

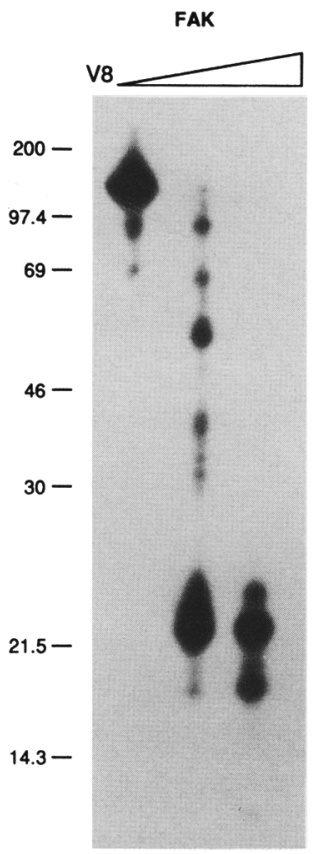

C

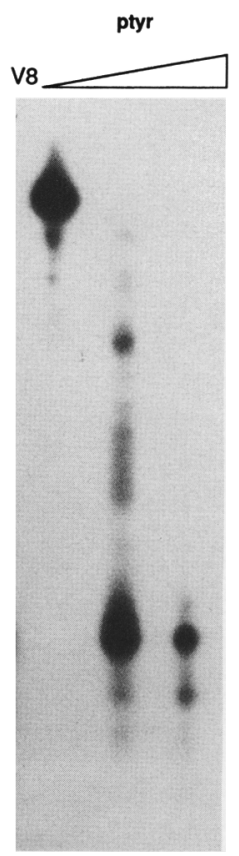

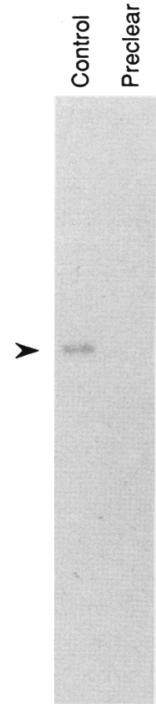
or $1 \mu \mathrm{g})$ was added, and SDS-PAGE was performed. Digestion occurred $(\sim 3 \mathrm{hr})$ until the samples reached the interface between the stacking and separating gel. After completion of electrophoresis, the polyacrylamide gel was fixed, stained, and exposed to autoradiography as described above. (V8) V8-protease from S. aureus; (FAK) immunoprecipitation with anti-FAK antibodies (mAb 2A7); (ptyr) immunoprecipitation with antiphosphotyrosine antibodies. $(C)$ Immunodepletion of brain extracts with anti-FAK antibodies depletes tyrosine-phosphorylated pp125 as detected in immunocomplex kinase assays. Aliquots (150 $\mu \mathrm{g}$ of protein) from brain extracts of wild-type mice were either mock-treated or subjected to immunoprecipitation with anti-FAK antibodies (mAb $2 A 7)$ as described for $A$. Immunoprecipitation, immunocomplex kinase assays with antiphosphotyrosine antibodies, and SDS-PAGE of both mock-treated (control) and FAK-depleted extract (preclear) were performed as described for Fig. 1C. (Control) Mock-treated extract; (preclear) FAK-depleted extract. The arrowhead indicates the position of ppl25.

sion has been described previously (Cooke and Perlmutter 1989; Grant et al. 1992; Umemori et al. 1992; Bare et al. 1993).

\section{FAK is expressed in the hippocampus in both neurons and astrocytes}

To further define FAK expression in the hippocampus at the cellular and subcellular level, we used immunohistochemistry to examine tissues and cultured neurons and astrocytes (a detailed description of FAK localization in brain regions will be presented elsewhere). FAK expression was revealed by immunostaining with $\mathrm{mAb}$ 2A7 (Fig. 5) and two separate polyclonal rabbit antisera raised to avian FAK (BC3) and to murine FAK (FadK). Similar patterns of staining were observed with the three antibodies and could be specifically competed with FAK protein. For example, mAb $2 A 7$ staining was competed with wild-type FAK protein [glutathione $S$-transferase (GST) fusion protein encoding avian FAK carboxy-terminal residues 687-1052 (GST-Cterm)] but not with FAK lacking the 2A7 epitope (residues 965-1035) [GST fusion protein encoding avian FAK carboxy-terminal residues 687-1052 [GST-Ctermdl965-1035)] (data not shown).
Astroglia were identified using antibodies to an astroglia-specific cytoskeletal protein [glial fibrillary acidic protein (GFAP)] (Wang et al. 1984), and axons were identified with antibodies to an axonal protein [neurofilament middle protein (NFM)] (Kaplan et al. 1991). Processes of astroglia in both the neuronal granule cell layer and in the hilus of the dentate gyrus stained for FAK and GFAP (Fig. 5). FAK was also found in axonal fiber bundles in the hilus of the dentate gyrus (Fig. 5). These bundles appear to be amyelinated axons of the mossy fiber pathway, which projects from the granule-cell neurons of the dentate gyrus to the pyramidal neurons in the CA3 region of the hippocampus. Because FAK was found in both neurons and glia in tissues, we next examined the subcellular localization of FAK using hippocampus primary neuronal and astroglial cultures.

\section{Cultured neural cells show FAK is not restricted to focal cell adhesions}

In cultured fibroblasts FAK has been described as restricted to focal adhesion contacts (Hanks et al. 1992; Schaller et al. 1992, 1993; Hildebrand et al. 1993). This does not appear to be the case in neurons and astroglia. 

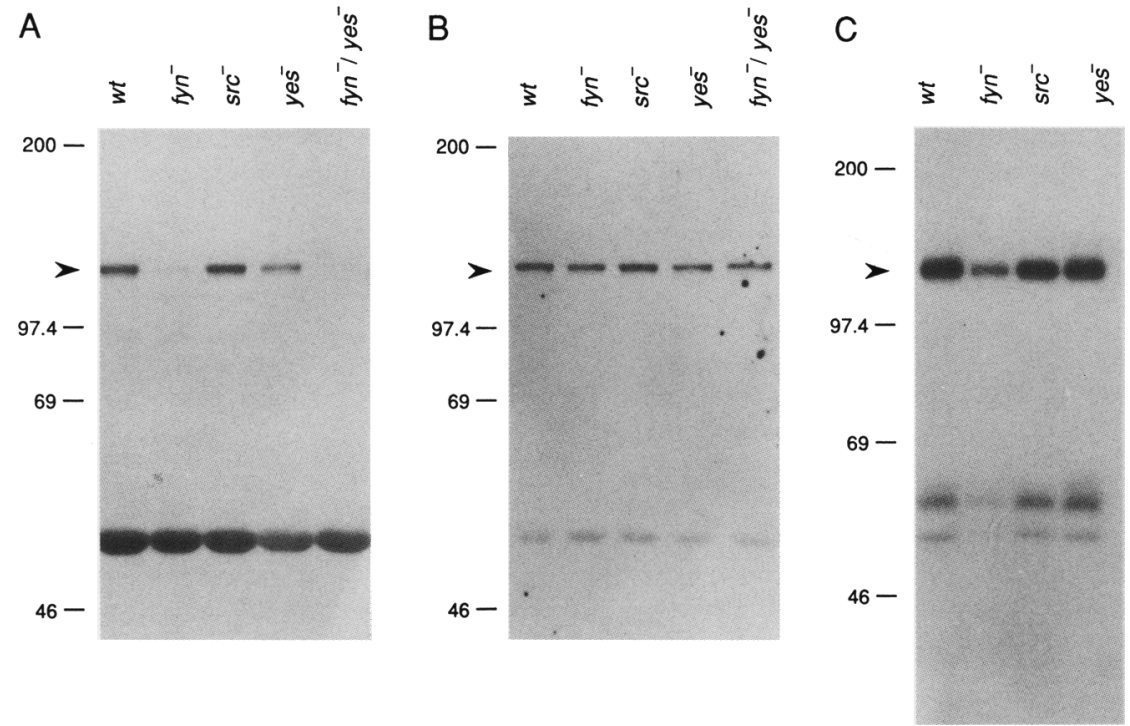

Figure 3. Hypophosphorylated FAK shows a reduced kinase activity in fyn mutant brains. (A) FAK is substantially less phosphorylated on tyrosine residues in fyn mutant brain. FAK was immunoprecipitated (mAb 2A7) from $1 \%$ digitonin extracts ( $150 \mu \mathrm{g}$ of protein) of either wild-type or fyn mutant brain as described for Fig. 1C. Proteins were then separated on an SDSpolyacrylamide gel $(12.5 \%$ acrylamide $)$, transferred onto a PVDF membrane, and immunolabeled with antiphosphotyrosine antibodies (mAb RC20). Bound antibodies were visualized with the ECL Detection System (Amersham). The arrowhead indicates the position of FAK. (B) Immunoprecipitation of FAK from wild-type and mutant brain extracts (mutant genes as indicated) reveals equal protein levels. The PVDF membrane from $A$ that was immunodecorated with antiphosphotyrosine anti bodies was stripped and reprobed with an anti-FAK polyclonal antiserum (BC3) as described above. (C) FAK autophosphorylation activity is reduced in fyn mutant extracts. Aliquots $(150 \mu \mathrm{g}$ of protein) from brain extracts of either wild-type or mutant mice (mutant genes as indicated) were subjected to immunoprecipitation with anti-FAK antibodies (mAb 2A7). Immunocomplex kinase assay, SDS-PAGE, KOH treatment, and autoradiography were then performed as described for Fig. $1 \mathrm{C}$. In the immunocomplex kinase assay with anti-FAK antibodies, an unidentified $57-\mathrm{kD}$ protein appeared to be associated with FAK (see Results).

We first immunostained type 1 astrocytes in culture with FAK antibodies and found staining throughout the cytoplasm in a filamentous pattern (Fig. 6A). An identical pattern of FAK immunostaining was found with three antibodies $(\mathrm{mAb} 2 \mathrm{~A} 7$ and rabbit polyclonals $\mathrm{BC} 3$ and FadK). As described in the previous section, the FAK immunostaining was specifically blocked by preincubation of antibodies with FAK protein.

To contrast FAK expression with the presence of focal

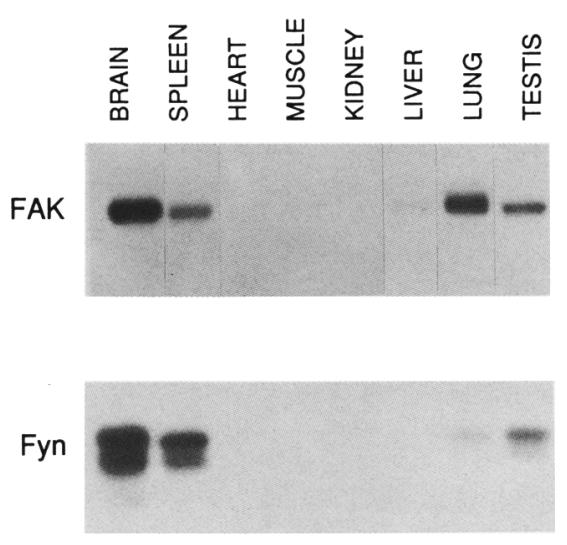

Figure 4. Neural expression of FAK and Fyn. FAK and Fyn are predominantly expressed in the brain. Fresh mouse tissues from forebrain, spleen, heart, skeletal muscle, kidney, liver, lung, and testis were prepared as described in Materials and methods. Aliquots (150 $\mu \mathrm{g}$ of protein) from these tissue extracts were subjected to immunoprecipitation with anti-FAK antibodies $(\mathrm{mAb}$ $2 \mathrm{~A} 7$, top) or with a Fyn-specific antiserum (bottom). Immunocomplex kinase assays, SDS-PAGE, $\mathrm{KOH}$ treatment, and autoradiography were then performed as described for Fig. $1 \mathrm{C}$. adhesions, we focused on astroglia that have well-defined focal adhesions. We stained astroglia with antibodies to the focal adhesion contact proteins, vinculin (Fig. 6B), talin, and tensin (Burridge et al. 1992), and observed the characteristic speckled pattern at points of contact with the extracellular matrix (Fig. 6B) (Abd-El-Basset et al. 1991; Ciesielski-Treska et al. 1991; Tawil et al. 1993). These double-labeling experiments clearly showed that in the same astrocytes that have prominent focal contacts, the majority of FAK was not in focal contacts but in a cytoplasmic cytoskeletal component. The cytoplasmic filamentous distribution of FAK suggested that FAK was associated with a component of the astroglial cytoskeleton. Type 1 astrocytes are unique in their expression of an intermediate filament protein known as GFAP (Wang et al. 1984). Immunostaining of astrocytes with antibodies to FAK and to GFAP showed an identical staining pattern indicating that FAK is associated with the astrocyte intermediate filament cytoskeleton (Fig. $6 \mathrm{C}, \mathrm{D})$. Thus, unlike fibroblasts, in astrocytes FAK is not a kinase that is primarily associated with focal contacts but appears to be associated with the cytoskeleton.

We examined FAK expression in neurons by immunostaining primary hippocampal neuronal cultures (Fig. 7). Using double-labeling with antibodies to a dendritic protein [microtubule-associated protein 2 (MAP2)] and an axonal protein (NFM) we found that FAK was distributed throughout the neuron including the cell body, dendritic tree, and axon. The staining of FAK in dendrites (Fig. 7A) had a granular appearance and did not have the filamentous staining seen with antibodies to MAP2 (Fig. 7B), which suggests that FAK is distributed in the cytoplasm. The distribution of FAK in both axons and dendrites and synaptosomes (data not shown) suggests that FAK may 
Figure 5. Fak is expressed in astroglia and neurons in the hippocampus. A fixed tissue section $(15 \mu \mathrm{m})$ of the dentate gyrus of the hippocampus was immunolabeled either with anti-FAK antibodies (mAb 2A7, left $)$ or with an anti-GFAP antisenum (antiserum 4151, middle) to stain astroglia. An adjacent section to the previous one was immunolabeled with an anti-NFM antiserum (NFLn, right) to identify axon bundles in the hilus of the dentate gyrus. These axon bundles that express FAK (left) represent the mossy fibers projecting from granule cell neurons to the CA3 region of the hippocampus. The immunostaining of FAK with the different antibodies could be specifically completed with recombinant FAK protein containing the $2 A 7$ epitope. The bound antibodies were visualized with fluores-
cent-labeled secondary antibodies as described in Materials and methods. Anti-FAK, anti-GFAP, anti-NFM, immunolabeling from fixed tissue sections with antibodies raised against FAK, GFAP, or NMP. The arrows indicate processes of astroglia; arrowheads indicate mossy fiber axon bundles. The position of the granule cell layer and the hilus of the dentate gyrus is indicated by brackets. Scale bar, $50 \mu \mathrm{m}$.

function in multiple compartments within the neuron. It will be necessary to use electron microscopic immunohistochemistry with anti-FAK antibodies to define the precise synaptic localization.

In summary, FAK is expressed at high levels in the brain in both astrocytes and neurons. Unlike the restricted expression to focal adhesions in fibroblasts, FAK is expressed in the cytoskeleton of astrocytes and throughout neurons. This suggests that FAK has different mechanisms for subcellular localization in neural cells and as a consequence has novel targets.

\section{Compensatory regulation between Fyn, Src, and Yes in mutant mice}

FAK was originally identified as a putative Src substrate (Kanner et al. 1990). Surprisingly, however, src mutants show neither a defect in FAK phosphorylation nor a detectable neurological phenotype. One possible explanation for this apparent paradox is that Fyn, Src, and Yes can each regulate FAK, but in Src mutants other src family kinases compensate by increasing their activity. We tested this idea and found in each of the mutants an increase in the activity of one or both of the remaining kinases.

Fyn, Src, and Yes kinase activities were measured by immunoprecipitation of each kinase with kinase-specific antibodies and in vitro phosphorylation of an artificial tyrosine kinase substrate (Fig. 8). Interestingly, distinct patterns of regulation emerged. First, the increase in activity was most dramatic in src mutants compared to fyn mutants and least in yes mutants. Second, evidence of functional associations between pairs of kinases seems to arise from these data. In fyn mutants, Src but not Yes activity was elevated relative to wild-type levels. This specific relationship was also observed in yes mutants, which showed an increase in Src but not Fyn activity. In src mutants, Fyn and Yes activity were both increased. This suggests that Src is linked to both Fyn and Yes but that Fyn and Yes are not linked to one another. To further explore this pattern we examined fyn/ yes double mutants and found a higher level of Src activity than in the single mutants (Fig. 8). Moreover, in fyn/yes double mutants, protein tyrosine phosphorylation and FAK phosphorylation (Figs. 1 and 3 ) and LTP (T.J. O'Dell, unpubl.) were not significantly different from that in fyn mutants. This specific biochemical pattern was further substantiated by a genetic analysis of double mutants, which revealed more severe phenotypes in $s r c / f y n$ and $s r c / y e s$ than in fyn/yes double mutants (Stein et al. 1994). The pairwise pattern implies that Src is more likely than Yes to cooperate with Fyn in signaling in the brain.

\section{Discussion}

Phenotypic analysis of $f y n$, src, yes, and $a b l$ mutant mice suggest that Fyn tyrosine kinase has a distinct biochemical role in the brain (Grant et al. 1992). To address this question, we have begun to analyze tyrosine-phosphorylated proteins in the brains of fyn mutants and compare these proteins with those of $s r c$ and yes mutants. We found that Fyn is specifically required for the tyrosine phosphorylation of nine proteins. To gain some insight into the function of the proteins that are hypophosphorylated, we focused on one and identified it as the nonreceptor tyrosine kinase FAK. We found that FAK has a novel subcellular localization and a specific requirement for Fyn in the brain.

\section{Subcellular localization of FAK in neurons and astrocytes}

FAK was originally identified in Src-transformed fibroblasts, where it is predominantly expressed at focal adhesion contacts (Kanner et al. 1990; Schaller et al. 1992). 

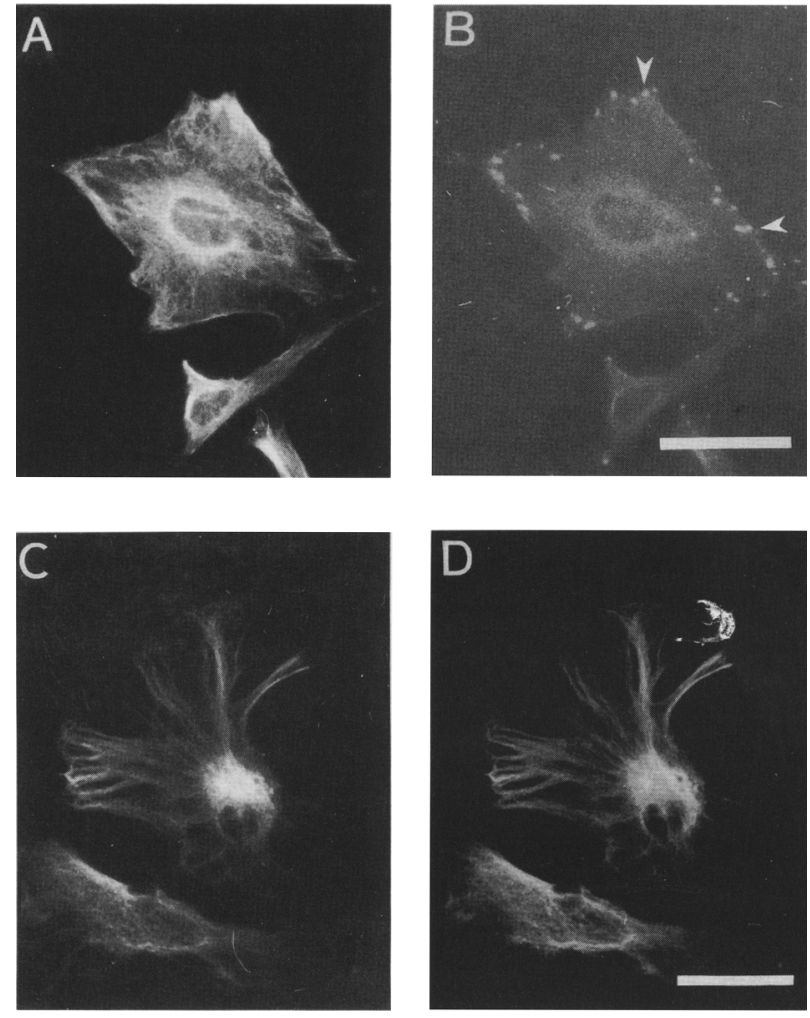

Figure 6. FAK is associated with the cytoskeleton in astrocytes. Note that FAK is not restricted to the focal contacts in these cells. Double immunolabeling of a representative cultured astrocyte was performed with anti-FAK antibodies (polyclonal antiserum FadK $)(A)$ and anti-vinculin antibodies $(\mathrm{mAb}$ hVIN-1) $(B)$; or with anti-FAK antibodies $(\mathrm{mAb} 2 \mathrm{~A} 7)(C)$ and anti-GFAP antibodies (polyclonal antiserum 4151) (D). The immunostaining of FAK with the indicated antibodies could be specifically competed with recombinant FAK protein containing the $2 \mathrm{~A} 7$ epitope. Astrocyte cultures were prepared as described in Materials and methods and immunolabeled as for Fig. 5 . Arrowheads indicate focal adhesions in astrocytes. Scale bars, $50 \mu \mathrm{m}$.

Focal contacts are a complex of cytoplasmic and membrane spanning proteins that connect the cytoskeleton to the extracellular matrix and adjacent cells (for review, see Burridge et al. 1988; Hynes 1992). In addition to contributing to the structural integrity within and between cells, focal contacts have been shown to transduce signals via integrin activation of FAK (Burridge et al. 1992; Guan and Shalloway 1992; Hanks et al. 1992; Kornberg et al. 1992; Lipfert et al. 1992; Shattil et al. 1994). Unlike the restricted localization of FAK to focal contacts in non-neural cells, we found that in neurons the majority of FAK is distributed in dendrites and axons and with the intermediate filament cytoskeleton in astrocytes. This suggests that FAK may have different mechanisms for subcellular localization in neural cells.

What mechanisms might account for this novel subcellular localization of FAK in neural cells? In fibroblasts the localization of FAK to focal adhesion contacts is directed by a carboxy-terminal domain named the focal adhesion targeting (FAT) sequence (Hildebrand et al. 1993). Moreover, the FAT sequence is sufficient to target a heterologous protein to focal contacts (Hildebrand et al. 1993). This raises the interesting possibility that in astrocytes, where focal contacts are clearly present, the FAT sequence may interact with a specific FAT-binding protein that targets FAK to the intermediate filaments rather than focal contacts. Preliminary data indicate the presence of novel brain isoforms of FAK that have altered FAT domains, which might subserve this role $(\mathrm{H}$. Asano and S. Grant, unpubl.). As a corollary to this different localization, FAK may have specific neural substrates and additional signaling roles to those found in fibroblasts.

\section{Fyn regulation of FAK in the brain}

We found that Fyn is specifically required to maintain FAK phosphorylation in mutant mice, suggesting that Fyn is a physiological regulator of FAK in the brain. The role of Fyn in FAK regulation is likely to be important for neural signaling, as the tyrosine phosphorylation of FAK regulates its kinase activity and interactions with signal transduction molecules. Moreover, FAK tyrosine phosphorylation is enhanced following activation of signal transduction pathways from multiple classes of receptors, including integrins, G-protein-coupled neuropeptide and neurotransmitter receptors, and tyrosine kinase growth factor receptors (Burridge et al. 1992; Guan and Shalloway 1992; Gutkind and Robbins 1992; Hanks et al. 1992; Kornberg et al. 1992; Lipfert et al. 1992; Zachary et al. 1992; Chen and Guan 1994; Hatai et al. 1994; Shattil et al. 1994).

We found that lack of Fyn in the brain results in both a reduction in FAK tyrosine phosphorylation and a reduction in FAK immunocomplex kinase activity. One explanation for our findings is that Fyn normally associates with and phosphorylates FAK and enhances its activity. This model is supported by in vitro studies, where it has been shown that the autophosphorylation of FAK (Tyr-397) promotes binding of the SH2 domain of Src family kinases, which then appear to phosphorylate FAK (Cobb et al. 1994; Schaller et al. 1994; Xing et al. 1994; Calalb et al. 1995). Thus FAK and Fyn appear to bind and form a two-subunit kinase complex.

FAK is tyrosine phosphorylated on at least four identified sites (Tyr-397, Tyr-407, Tyr-576, and Tyr-577) (Calalb et al. 1995). FAK autophosphorylation on Tyr-397 creates a high-affinity binding site for the $\mathrm{SH} 2$ domain of Src family kinases (Cobb et al. 1994; Schaller et al. 1994). In vitro and in vivo studies suggest that Src can enhance the phosphorylation (by trans-phosphorylation) of Tyr407, Tyr-576, and Tyr-577 (Calalb et al. 1995). Importantly, both Tyr-576 and Tyr-577 are conserved residues within the kinase domain and are known to be involved with regulating kinase activity, and their increased phosphorylation correlates with increased FAK kinase activity (Calalb et al. 1995). Our in vivo findings suggest that the absence of Fyn reduces the phosphorylation at sites Tyr-576 and Tyr-577, which results in a reduced FAK activity. 

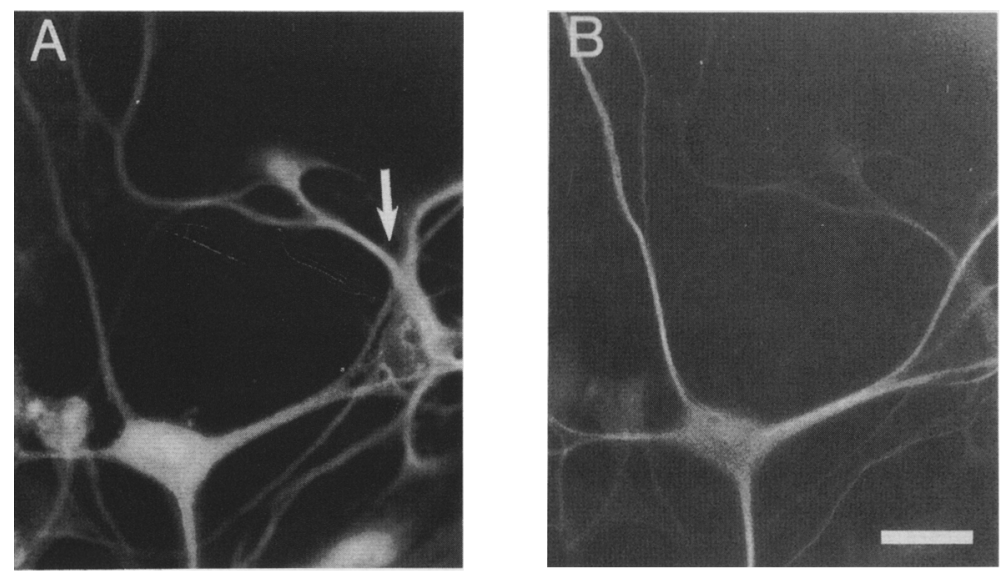

Figure 7. FAK is expressed in axons, dendrites, and neuronal cell bodies. Double immunolabeling of a representative cultured hippocampal neuron was performed with antibodies to FAK (polyclonal antiserum $\mathrm{FadK} /(A)$ and the dendritic protein MAP2 (mAb MAP2) (B). The arrow in $A$ indicates a FAKpositive astrocyte. Scale bars, $25 \mu \mathrm{m}$. Double immunolabeling of a representative cultured hippocampal neuron within a field of cocultured astrocytes was performed with antibodies to FAK (mAb 2A7) $|C|$ and the axonal neurofilament protein (NFM, polyclonal antiserum NFLn) (D). The culture of hippocampal neurons is described in Materials and methods. Immunolabeling was performed as described for Fig. 6 . The arrowhead indicates a representative neuronal cell body and its axon is indicated by the arrows. Scale bars, $50 \mu \mathrm{m}$.
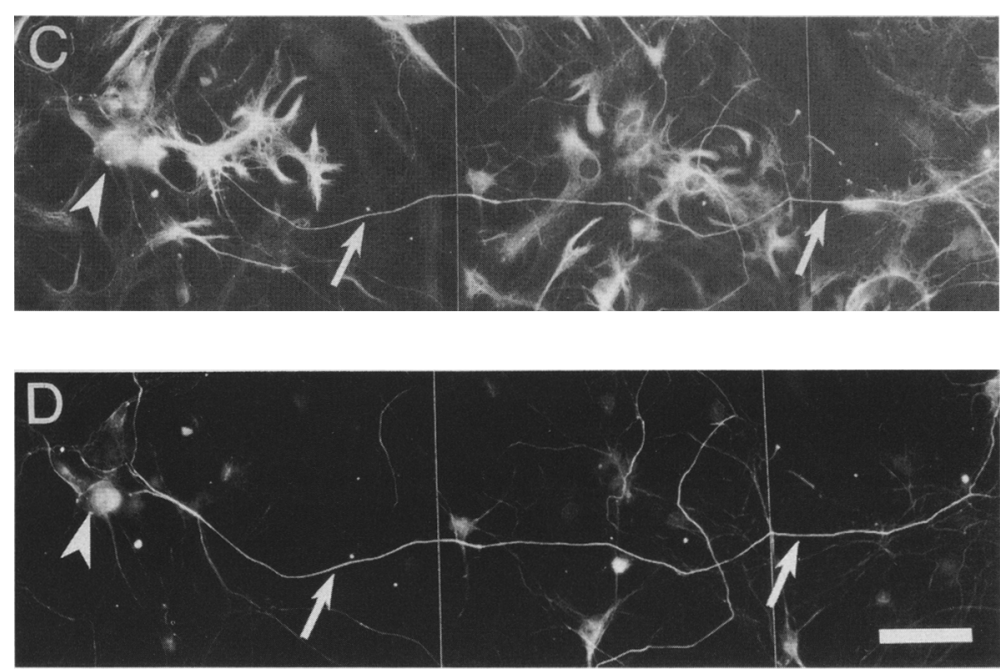

An important consequence resulting from the hypophosphorylation of FAK is that FAK-dependent signaling complexes will be reduced. The tyrosine phosphorylation of FAK is necessary for directing the assembly of such complexes through the interaction of FAK pTyrcontaining sites with $\mathrm{SH} 2$ domains in signaling molecules (for review, see Pawson 1995). Tyrosine-phosphorylated FAK has been shown to bind to SH2-containing proteins involved with signal transduction other than Fyn, Src, and Yes and include carboxy-terminal Src kinase (CSK), phosphatidylinositol-3-OH kinase, GRB2 (SH2/SH3 adaptor protein), and the $\mathrm{SH} 2$ domains of NCK (SH2/SH3 adaptor protein) and phospholipase $\mathrm{C}-\gamma$ (Chen and Guan 1994; Cobb et al. 1994; Schlaepfer et al. 1994). The fyn mutant mice provide a unique system to study the role of FAK, its phosphorylation, and associated signaling molecules in the brain. For example, by crossing Fyn and FAK mutant mice, it will be possible to manipulate the level of FAK phosphorylation and activity to further test the importance of FAK in the fyn neural phenotype. Moreover, electrophysiological studies of neural signaling pathways in fyn mutants (and FAK mutants) may reveal specific physiological roles for FAK and its associated proteins.
Does FAK have a signaling role in LTP?

The induction of LTP requires an elevation of $\mathrm{Ca}^{2+}$ and activation of several kinases including $\mathrm{PKC}$ in the postsynaptic neuron (Malenka et al. 1989; Malinow et al. 1989; Bliss and Collingridge 1993). Because the tyrosine phosphorylation of FAK is regulated by $\mathrm{Ca}^{2+}, \mathrm{PKC}(\mathrm{Ha}-$ mawy et al. 1993; Sinnett-Smith et al. 1993; Vuori and Ruoslahti 1993), and Fyn, then FAK may be a component of a postsynaptic mechanism involved with LTP. Moreover, neurotransmitter and neuropeptide receptors have been shown to stimulate FAK tyrosine phosphorylation (Gutkind and Robbins 1992; Zachary et al. 1992) and the tyrosine phosphorylation of potassium channels (Huang et al. 1993). FAK and Fyn might also phosphorylate and regulate structural proteins in the brain, as FAK is associated with the cytoskeleton and fyn mutants reveal abnormal neural architecture in the hippocampus (Grant et al. 1992). Interestingly, the induction of LTP and kindling, which both require Fyn, normally results in a number of morphological changes including an increase in the number of synapses and alterations in postsynaptic spine structure and astrocyte shape (for review, see Wallace et al. 1991; Bailey and Kandel 1993). 


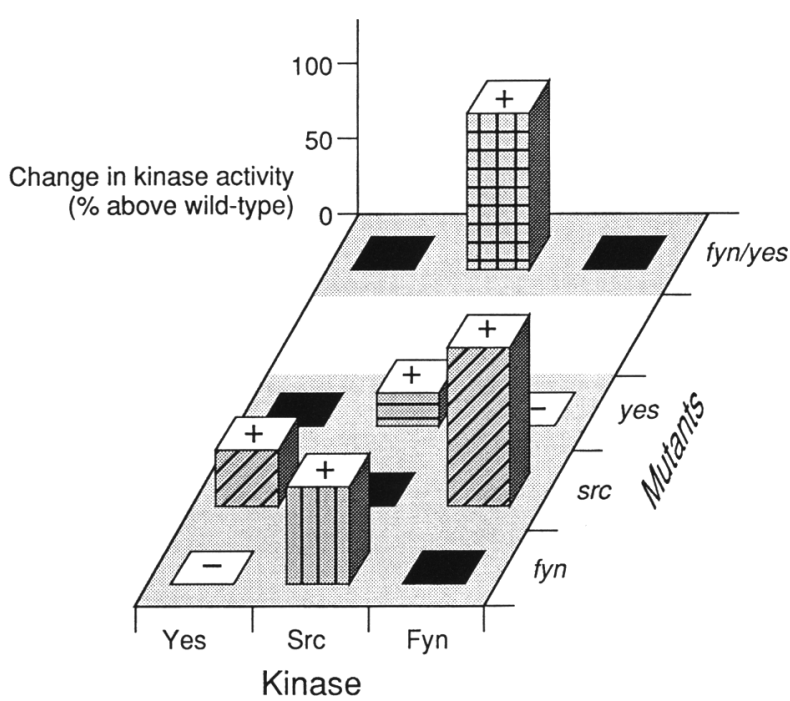

Figure 8. Compensatory increase in Src family kinase activity in mutant mice. Aliquots ( $150 \mu \mathrm{g}$ of protein) from brain lysates of either wild-type or mutant mice (mutated genes as indicated, horizontal rows) were subjected to immunoprecipitation with a polyclonal rabbit antiserum raised against a peptide unique to Fyn (right vertical row), monoclonal antibodies against Src (mAb 327, middle vertical row), and a polyclonal rabbit antiserum raised against a peptide unique to Yes (gift of J.B. Bolen, left vertical row). The kinase activity was measured in a phosphorylation reaction with the artificial polypeptide (poly[Glu, Tyr]x in the ratio of $4: 1$, Sigma) as described in Materials and methods. The kinase activities of individual Src family members from mutant brain extracts were expressed as changes in kinase activity above the wild-type value (columns in the $z$-axis). ( $\mathrm{Mu}$ tants) Brain extracts of the indicated mouse mutants in italics; (kinase) kinase activity of the indicated enzyme; $(+)$ a compensatory increase of a kinase in response to a mutated gene. Values of the individual columns: (1) fyn: $0 \%$ (Fyn); $61 \% \pm 8 \%{ }^{*}, n=7$ (Src); $5 \% \pm 3 \%, n=10$ (Yes); (2) src: $105 \% \pm 16 \%^{*}, n=7$ (Fyn); $0 \%$ (Src); $36 \% \pm 5 \%{ }^{*}, n=10$ (Yes); (3) yes: $5 \% \pm 3 \%, n=6$ (Fyn); $21 \% \pm 6 \% * n=6 \quad(\mathrm{Src}) ; 0 \%$ (Yes); (3) fyn/yes: $0 \%$ (Fyn); $118 \% \pm 23 \% *, n=4(\mathrm{Src}) ; 0 \%$ (Yes). Asterisks indicate a significant increase judged from Student's $t$-test $(\mathrm{P}<0.05)_{;}(n)$ the total number of assays for the specific kinase.

\section{Compensatory regulation of nonreceptor tyrosine kinases in the brain of mutant mice}

The absence of either a synaptic phenotype or changes in protein tyrosine phosphorylation in src mutants was puzzling. Src can regulate FAK in transformed cells (Kanner et al. 1990; Guan and Shalloway 19921, and multiple lines of evidence suggest Src to be important in the brain (Cotton and Brugge 1983; Brugge et al. 1985; Levy et al. 1987; Maness et al. 1988; Sobue and Kanda 1988; Barnekow et al. 1990; Pyper and Bolen 1990; Cudmore and Gurd 1991; Linstedt et al. 1992). We found an increase in the activity of Src family kinases in mutant brains, suggesting that when one kinase is absent the other kinases are activated. Our data suggest that Fyn and Yes functionally replace Src in mutant mice and that Src has a significant role in the normal brain. This con- clusion is supported by the complementary data from double mutant mice, which show that $f y n / s r c$ double mutants are further impaired than the single mutants (Stein et al. 1994) and fyn/yes double mutants show LTP that is indistinguishable from fyn mutants (T. O'Dell, S. Grant, E. Kandel, unpubl.).

The compensatory responses appear to not only involve related molecules but other components of the affected pathways. For example, we found that CSK, which phosphorylates and negatively regulates Src family kinases, is also altered in the fyn, src, and yes mutants (data not shown). Compensatory and homeostatic regulation between related molecules in mutant mice is likely to be a common phenomenon (Rudnicki et al. 1992; Hummler et al. 1994; Lowell et al. 1994) and, in the brain, may play a significant role in the interpretation of mutant neural phenotypes other than in only masking deficits. The combined use of biochemistry with mouse germ-line mutations will help determine the importance of compensation and will further the dissection of tyrosine kinase signaling pathways required for vertebrate cognitive function.

\section{Materials and methods}

Mice were housed and euthanized according to the institutional guidelines and IACUC procedures.

\section{Protein extracts}

Fresh forebrains or peripheral tissues from wild-type and $\mathrm{mu}$ tant mice were lysed with a motor-driven glass/Teflon homogenizer (Eberbach; 10 passes, $400 \mathrm{rpm}, 0^{\circ} \mathrm{C}$ ) in $5 \mathrm{ml}$ of buffer. Two different lysis buffers were used in this study: $(1)$ a digitonin buffer: $1 \%$ digitonin, $50 \mathrm{~mm}$ Tris- $\mathrm{HCl}(\mathrm{pH} 7.5), 30 \mathrm{~mm}$ Na-pyrophosphate, $50 \mathrm{mM} \mathrm{NaF}$, and $20 \mathrm{mM} \mathrm{ZnCl}_{2}$ or (2) a modified RIPA buffer: $1 \%$ Triton X-100, $0.1 \%$ SDS, $1 \%$ deoxycholate, 158 $\mathrm{mm} \mathrm{NaCl}, 10 \mathrm{~mm}$ Tris- $\mathrm{HCl}$ (pH 7.5), and $5 \mathrm{~mm}$ EDTA (Harlow and Lane 1988). Both buffers also included $1 \mathrm{~mm} \mathrm{Na-vanadate,}$ $25 \mu \mathrm{g} / \mathrm{ml}$ of [4-(2-aminoethyl)-benzenesulfonylfluoride, $\mathrm{HCl}$ ], 1 $\mu \mathrm{g} / \mathrm{ml}$ of aprotonin, and $0.5 \mu \mathrm{g} / \mathrm{ml}$ of leupeptin. The lysate was centrifuged $\left(25,000 \mathrm{~g}, 30 \mathrm{~min}, 4^{\circ} \mathrm{C}\right)$ and the supernatant (extract) was assayed for protein concentration (protein assay micro-BCA reagent kit, Pierce), frozen in liquid nitrogen, and stored at $-70^{\circ} \mathrm{C}$. Extracts prepared in either digitonin or RIPA buffer showed similar results in immunoprecipitations, Western blotting and immunocomplex kinase assays (data not shown).

\section{Immunoprecipitation}

Immunoprecipitation was essentially as described in Harlow and Lane (1988). Protein $(150 \mu \mathrm{g})$ was incubated with the indicated polyclonal antiserum or monoclonal antibodies $(1 \mu \mathrm{g}$, or supplier's recommendation) by gentle inversion $\left(1 \mathrm{hr}, 4^{\circ} \mathrm{C}\right)$. Protein G-agarose beads ( $10 \mu$ l, Pharmacia) were added and then incubated at $4^{\circ} \mathrm{C}$ for another hour. The immune complexes were isolated by centrifugation $(6000 \mathrm{~g}, 10 \mathrm{sec})$, washed twice with lysis buffer, and once with Tris-buffered saline (TBS; $150 \mathrm{mM}$ $\mathrm{NaCl}, 50 \mathrm{mM}$ Tris- $\mathrm{HCl}$ at $\mathrm{pH} 7.2$, including $100 \mu \mathrm{M} \mathrm{Na-vana-}$ date). The following antibodies were used for immunoprecipitations: monoclonal antibodies raised against antiphosphotyrosine residues (mAb 4G10, gift of B. Druker, Oregon Health Sciences University, Portland), FAK (mAb 2A7, gift of J.T. Parsons, University of Virginia Health Sciences Center, Charlottes- 
ville); and polyclonal rabbit antisera raised against residues 29 48 of Fyn (gifts of J.B. Bolen, Bristol-Myers Squibb, Princeton, NJ, or Upstate Biotech. Inc.).

\section{Kinase assays}

For immunocomplex kinase autophosphorylation assays, the protein G-agarose beads carrying the bound immune complexes were additionally washed with kinase buffer $(10 \mathrm{mM}$ Tris- $\mathrm{HCl}$ at $\mathrm{pH} 7.2,5 \mathrm{mM} \mathrm{MgCl}, 5 \mathrm{mM} \mathrm{MnCl}_{2}$ ), then incubated ( $3 \mathrm{~min}$, $\left.25^{\circ} \mathrm{C}\right)$ with $\left[\gamma^{-32} \mathrm{P}\right] \mathrm{ATP}(1 \mu \mathrm{M}, 10 \mu \mathrm{Ci}$ in total volume of $40 \mu \mathrm{l})$. The autophosphorylation reaction was stopped by the addition of $20 \mathrm{~mm}$ EDTA in TBS, and the beads were collected by centrifugation. Bound proteins were dissociated from the beads by incubation $\left(5 \mathrm{~min}, 95^{\circ} \mathrm{C}\right.$ ) in sample buffer (Laemmli 1970) and subjected to SDS-PAGE (1.0-mm spacers, $8 \%$ acrylamide gels; $30 \%$ acrylamide stock solution contained $0.8 \%$ bisacrylamidel. Polyacrylamide gels were fixed $50 \%$ methanol, $10 \%$ acetic acid for $30 \mathrm{~min}$, and then $10 \%$ methanol, $10 \%$ acetic acid for 30 min), incubated in $1 \mathrm{M} \mathrm{KOH}\left(2 \mathrm{hr}, 56^{\circ} \mathrm{C}\right)$ with gentle agitation to hydrolyze phosphorylation on serine/threonine residues and rinsed twice for $20 \mathrm{~min}$ in $10 \%$ acetic acid, $10 \%$ methanol. Finally, the polyacrylamide gels were dried for autoradiography (Kodak XAR film).

For substrate phosphorylation assays, either an artificial peptide (poly[Glu,Tyr]x in the ratio of $4: 1$; Sigma; $1.6 \mu \mathrm{g}$ ) (Braun et al. 1984) or acid-treated enolase (5 $\mu \mathrm{g}$; Boehringer Mannheim) (Clarke and Brugge 1993) was used. The phosphorylation reaction was initiated by the addition of $\left[\gamma^{32} \mathrm{P}\right]$ ATP as described above and stopped with $25 \mathrm{~mm}$ EDTA in fivefold concentrated sample buffer. For quantitation of activity, the bands (FAK autophosphorylation, Fig. 3C) or lanes (substrate phosphorylation, Fig. 8) were excised and counted by liquid scintillation.

\section{V8-protease digestion}

Labeled bands from immunocomplex kinase assays (as in Fig. 2A) were excised from the SDS-polyacrylamide gels and rehydrated in $62.5 \mathrm{mM}$ Tris- $\mathrm{HCl}|\mathrm{pH} 6.8|, 0.1 \%$ SDS, $10 \%$ glycerol, and $10 \mu \mathrm{g} / \mathrm{ml}$ of bromophenol blue. Each of these acrylamide gel pieces was manually chopped and loaded into three wells of a second SDS-polyacrylamide gel $(1.5-\mathrm{mm}$ spacers, $12.5 \%$ acrylamide). V8-protease (Staphylococcus aureus; $0,0.1$, or $1 \mu \mathrm{g}$ diluted in $250 \mu$ l of rehydration buffer) was added into the wells. Digestion occurred during a 3 -hr period until samples reached the interface between the stacking and separation gel. SDSPAGE was finished, and the polyacrylamide gel was fixed and stained, and autoradiography performed as described above.

\section{Western blotting}

Proteins from extracts or immunocomplexes bound to protein G-agarose beads were subjected to SDS-PAGE and then transferred onto PVDF membranes (Protein Images, U.S. Biochemical), backed up by nitrocellulose (Schleicher \& Schuell BA83). Transfer occurred in blotting buffer $(10 \mathrm{~mm}$ CAPS at $\mathrm{pH} 11,15 \%$ methanol) by a two-step protocol ( $30 \mathrm{~min}$ at $100 \mathrm{~mA}$, then 30 $\min$ at $300 \mathrm{~mA}$. To block nonspecific binding, the membrane was incubated either with $10 \%$ horse serum, $2 \%$ nonfat dry milk, $2 \%$ BSA, and 1\% Tween 20 in TBS /for polyclonal antisera) or with $2 \%$ BSA, $0.05 \%$ Tween 20 in TBS (for monoclonal antibodies) at room temperature (RT) on a rocking platform for $\mathrm{l} \mathrm{hr}$. The membranes were incubated with the indicated antibodies (dilutions are listed below) in 0.5-fold concentrated blocking buffer ( $1 \mathrm{hr}$ at RT). After washing $(3 \times 10 \mathrm{~min})$ in TBST buffer (TBS including $0.05 \%$ Tween 20 ), the blot was incubated with horseradish peroxidase (HRP)-conjugated secondary anti- bodies (donkey anti-rabbit HRP or goat anti-mouse HRP, Amersham) in 0.5 -fold concentrated blocking buffer ( $1 \mathrm{hr}$ at RT). Following extensive washing, the bands were visualized using chemiluminesence (ECL Western Blotting System, Amersham). To reprobe with another antibody, the membrane was stripped by incubating twice in $0.2 \mathrm{M}$ glycine $(\mathrm{pH} 2.5)$ and $0.05 \%$ Tween 20 at $80^{\circ} \mathrm{C}$, then rinsing twice ( $15 \mathrm{~min}$ at RT) with $0.09 \mathrm{M}$ boric acid ( $\mathrm{pH} 7.4), 0.9 \% \mathrm{NaCl}$, and $0.05 \%$ Tween 20 . The membranes were then blocked and incubated with the next antibody. To verify effective protein transfer and equal protein loading, the nitrocellulose backup membrane was stained with a protein gold stain according to manufacturer's instructions (Gold Blot Stain, Integrated Separation Systems).

The following antibodies were used for Western blotting in the indicated dilutions: antiphosphotyrosine antibodies $1 \mathrm{mAb}$ RC20 conjugated with HRP, Transduction Labs.; 1:2500|, FAK (polyclonal rabbit antiserum BC3, gift of J.T. Parsons; 1:500), Src (mAb 327, Oncogene Science, 1:1000), or polyclonal rabbit antisera raised against residues $29-48$ of Fyn or residues 5-50 of Yes (gifts of J. B. Bolen; 1:500).

\section{Immunohistochemistry}

Tissues Brains from anesthetized mice (strain C57B16/J) were isolated, bisected in the sagittal plane, frozen in powdered dry ice, and stored at $-70^{\circ} \mathrm{C}$. The tissue was embedded (Tissue-Tek, Miles) and serial sagittal sections $(15 \mu \mathrm{m})$ were prepared with a cryomicrotome (Hacker Instruments) on polylysine-coated glass microscope slides, and then stored at $-70^{\circ} \mathrm{C}$. Sections were thawed to room temperature in a vacuum dessicator (15 min), fixed in $100 \%$ methanol $\left(10 \mathrm{~min}, 20^{\circ} \mathrm{C}\right)$, washed with TBS $(3 \times 3 \mathrm{~min}, \mathrm{RT})$, permeabilized with $0.05 \%$ Triton $\mathrm{X}-100(10 \mathrm{~min}$, RT), and washed again with TBS. Sections were incubated with $10 \%$ horse serum and $10 \%$ goat serum $(1 \mathrm{hr}, \mathrm{RT})$ to block nonspecific binding of antibodies, and the indicated primary antibodies (dilutions listed below) were added in blocking buffer. After incubation $\left(16 \mathrm{hr}, 4^{\circ} \mathrm{C}\right)$ the sections were washed with TBS $(5 \times 3 \mathrm{~min}, \mathrm{RT})$, and incubated with fluorescent-tagged secondary antibodies (below) in blocking buffer ( $1 \mathrm{hr}, \mathrm{RT})$. After washing with TBS, coverslips were mounted in Mowiol (Harlow and Lane 1988) and 2.5\% 1,4-diazabicyclo-[2.2.2]octane (Sigma).

Cell culture Primary cultures of neurons and astroglia were prepared as described below. The cells were washed in TBS $(3 \times 60 \mathrm{sec}, \mathrm{RT})$, fixed in $100 \%$ methanol $\left(10 \mathrm{~min}, 20^{\circ} \mathrm{C}\right)$, and immunostaining was performed as described for tissues.

The following antibodies were used for immunohistochemistry in the indicated dilutions: FAK (mAb 2A7, 1:100; BC3, 1: 500; FadK, 1:500), GFAP (4151, polyclonal rabbit antiserum raised to human GFAP; gift of R. Liem, 1:1000), NFM (NFLn, polyclonal rabbit antiserum raised against an amino-terminal peptide of neurofilament protein, gift of $\mathrm{R}$. Liem, Columbia University, New York, NY, 1:1000), vinculin (mAb hVIN-1, Sigma, 1:200), talin (N681, polyclonal rabbit antiserum raised against purified human platelet talin, gift of $K$. Burridge, 1:200), tensin (mAb 215, gift of K. Burridge, University of North Carolina, Chapel Hill, 1:100). FAK antibodies were preadsorbed with recombinant FAK protein $(10 \mu \mathrm{g})$ by incubation in TBS and rotation at $4^{\circ} \mathrm{C}$ for $16 \mathrm{hr}$. Bound antibodies were visualized with the following secondary antibodies: Cy3TM-conjugated affinipure $F\left(a b^{\prime}\right) 2$ fragment goat anti-rabbit IgG, $F\left(a b^{\prime}\right) 2$ fragment specific (1:500, Jackson Immunoresearch Labs.), fluoroscein (FITC)-affinipure F $\left(\mathrm{ab}^{\prime}\right) 2$ fragment goat anti-mouse IgG, F(ab') fragment specific $(1: 200$, Jackson Immunoresearch Labs). Fluorescent photomicroscopy was performed on a Zeiss Axioplan microscope (Ilford HP5 film). 


\section{Cell culture}

Astrocyte (Levison and McCarthy 1991) and hippocampal neuronal cultures (Goslin and Banker 1991) were prepared using established techniques. Astrocytes were grown on fibronectincoated glass slides and neurons were cultured on glass coverslips coated with laminin and polylysine.

\section{Acknowledgments}

Special thanks go to Paul Stein and Philippe Soriano for providing mutant mice. We thank Kari Alitalo, Mathias Bergman, Dusan Bartsch, Joe Bolen, Joan Brugge, Kieth Burridge, Jonathon Cooper, Brian Druker, Jim Goldman, Ron Liem, Tom Parsons, Michael Shelanski, and Mike Schaller for reagents and valuable advice, and Richard Axel, Bina Santoro, Paul Stein, Philippe Soriano, and Sheila Thomas for comments on an earlier draft of the manuscript. S.G. was supported by grants from the New York State Psychiatric Institute and the Alzheimer's Disease Research Center of New York. M.K. was supported by a postdoctoral fellowship from the Deutsche Forshungsgemeinschaft. This work was supported by grants from the National Institutes of Health to E.R.K. E.R.K. is a Senior Investigator of the Howard Hughes Medical Institute.

The publication costs of this article were defrayed in part by payment of page charges. This article must therefore be hereby marked "advertisement" in accordance with 18 USC section 1734 solely to indicate this fact.

\section{References}

Abd-El-Basset, E.M., I. Ahmed, and S. Federoff. 1991. Actin and actin-binding proteins in differentiating astroglia in tissue culture. $/$. Neurosci. Res. 30: 1-17.

Abeliovich, A., C. Chen, Y. Goda, A.J. Silva, C.F. Stevens, and S. Tonegawa. 1993a. Modified hippocampal long-term potentiation in PKC $\gamma$-mutant mice. Cell 7: 1253-1262.

Abeliovich, A., R. Paylor, C. Chen, J.J. Kim, J.M. Wehner, and S. Tonegawa. 1993b. PKCy-mutant mice exhibit moderate deficits in spatial and contextual learning. Cell 75: 1263-1272.

Aiba A., C. Chen, K. Herrup, C. Rosenmund, C.F. Stevens, and S. Tonegawa. 1994. Reduced hippocampal long-term potentiation and context-specific deficit in associative learning in mGluR1 mutant mice. Cell 79: 365-375.

Andre, E. and M. Becker-Andre. 1993. Expression of an N-terminally truncated form of human focal adhesion kinase in brain. Biochem. Biophys. Res. Commun. 190: 140-147.

Appleby, M.W., J.A. Gross, M.P. Cooke, S.D. Levin, X. Qian, and R.M. Perlmutter. 1992. Defective T-cell receptor signaling in mice lacking the thymic isoform of $\mathrm{p} 59^{f y n}$. Cell 70: 751-763.

Bailey, C.H. and E.R. Kandel. 1993. Structural changes accompanying memory storage. Annu. Rev. Physiol. 55: 397-426.

Bare, D.J., J.M. Lauder, M.B. Wilkie, and P.F. Maness. 1993. p5 $9^{f y n}$ in rat brain is localized in developing axonal tracts and subpopulations of adult neurons and glia. Oncogene 8: 1429-1436.

Barnekow, A., R. Jahn, and M. Schartl. 1990. Synaptophysin: A substrate for the protein tyrosine kinase $\mathrm{pp} 60^{\mathrm{c}-\mathrm{src}}$ in intact synaptic vesicles. Oncogene 5: 1019-1024.

Beggs, H.E., P. Soriano, and P.F. Maness. 1994. NCAM-dependent neurite outgrowth is inhibited in neurons from Fynminus mice. I. Cell. Biol. 127: 825-833.

Bliss, T.V.P. and G.L. Collingridge. 1993. A synaptic model of memory: Long-term potentiation in the hippocampus. $\mathrm{Na}$ ture 361: 31-39.
Bolen, J.B., P.A. Thompson, E. Eiseman, and I.D. Horak. 1991. Expression and interactions of the Src family of tyrosine protein kinases in T lymphocytes. Adv. Cancer Res. 57: 103149.

Bolen, J.B., R.B. Rowley, C. Spana, and A.Y. Tsygankov. 1992. The Src family of tyrosine protein kinases in hemopoietic signal transduction. FASEB /. 6: 3403-3409.

Bourtchuladze, R., B. Frenguelli, J. Blendy, D. Cioffi, G. Schutz, and A.J. Silva. 1994. Deficient long-term memory in mice with a targeted mutation of the cAMP-responsive elementbinding protein. Cell 79: 59-68.

Braun, S., W.E. Raymond, and E. Racker. 1984. Synthetic tyrosine polymers as substrates and inhibitors of tyrosine specific protein kinases. J. Biol. Chem. 259: 2051-2054.

Brugge, J.S., P.C. Cotton, A.E. Querel, J.N. Barrett, D. Nonner, and R.W. Keane. 1985. Neurons express high levels of a structurally modified, activated form of $\mathrm{pp} 60^{\mathrm{c}-\mathrm{src}}$. Nature 316: $554-557$.

Burridge, K., K. Fath, T. Kelly, G. Nuckolls, and G. Turner. 1988. Focal Adhesion: Transmembrane junctions between the extracellular matrix and the cytoskeleton Annu. Rev. Cell Biol. 4: 487-525.

Burridge, K., C.E. Turner, and L.J. Romer. 1992. Tyrosine-phosphorylation of paxillin and pp $125^{\text {Fak }}$ accompanies cell adhesion to extracellular matrix: A role in cytoskeletal assembly. J. Cell. Biol. 119: 893-903.

Cain, D.P., S.G.N. Grant, D. Saucier, E.L. Hargreaves, and E.R. Kandel. 1995. Fyn tyrosine kinase is required for normal amygdala kindling. Epilepsy Res. 22: (in press).

Calalb, M.B., T.R. Polte, and S.K. Hanks. 1995. Tyrosine phosphorylation of focal adhesion kinase at sites in the catalytic domain regulates kinase activity: A role for Src family kinases. Mol. Cell. Biol. 15: 954-963.

Chan, A.C., D.M. Desai, and A. Weiss. 1994. The role of protein tyrosine kinases and protein tyrosine phosphatases in $\mathrm{T}$ cell antigen receptor signal transduction. Annu. Rev. Immunol. 12: $555-592$.

Chen, H.C and J.L. Guan. 1994. Stimulation of phosphatidylinositol 3'-kinase association with focal adhesion kinase by platelet-derived growth factor. I. Biol. Chem. 269: 3122931233.

Ciesielski-Treska, J., G. Ulrich, O. Baldacini, H. Monteil, and D. Aunis. 1991. Phosphorylation of cellular proteins in response to treatment with Clostridium difficile toxin B and Clostridium sordellii toxin L. Eur. I. Cell Biol. 56: 68-78.

Clarke, E.A. and J.S. Brugge. 1993. Redistribution of activated pp $60^{\text {c-src }}$ to integrin-dependent cytoskeletal complexes in thrombin stimulated platelets. Mol. Cell. Biol. 13: 18631871.

Cobb, B.S., M.D. Schaller, T.-H. Leu, and J.T. Parsons. 1994. Stable association of $\mathrm{pp} 60^{\text {src }}$ and $\mathrm{pp} 59^{\text {fyn }}$ with the focal adhesion-associated protein tyrosine kinase, ppl25 $5^{\mathrm{Fak}}$. Mol. Cell. Biol. 14: 147-155.

Conquet, F., Z.I. Bashir, C.H. Davies, H. Daniel, F. Ferraguti, F. Bordi, K. Franz-Bacon, A. Reggiani, V. Matarese, F. Conde, G.L. Collingridge, and F. Crépel. 1994. Motor deficit and impairment of synaptic plasticity in mice lacking mGluRl. Nature 372: 237-243.

Cooke, M.P. and R.M. Perlmutter. 1989. Expression of a novel form of the fyn proto-oncogene in hematopoietic cells. New Biol. 1: 66-74.

Cooper, J.A. 1990. The Src family of protein-tyrosine kinases. In Peptides and protein phosphorylation (ed. B. Kempl, pp. 85113. CRC Press, Boca Raton, FL.

Cooper, J.A. and B. Howell. 1993. The when and how of Src regulation. Cell 73: 1051-1054. 
Cotton, P.C. and J.S. Brugge. 1983. Neural tissues express high levels of the cellular Src gene product pp60 $60^{\text {ssrc }}$. Mol. Cell. Biol. 3: 1157-1162.

Cudmore, S.B. and J.W. Gurd. 1991. Postnatal age and protein tyrosine-phosphorylation at synapses in the developing rat brain. I. Neurochem. 57: 1240-1248.

Davidson, D., J. Viallet, and A. Veillette. 1994. Unique catalytic properties dictate the enhanced function of $\mathrm{p} 59^{f y n} T$, the hemopoitic cell-specific isoform of the Fyn tyrosine protein kinase, in T cells. Mol. Cell. Biol. 14: 4554-4564.

Gauen, L.K.T., A.-N.T. Kong, L.E. Samelson, and A.S. Shaw. 1992. p59fyn tyrosine kinase associates with multiple T-cell receptor subunits through its unique amino-terminal domain. Mol. Cell. Biol. 12: 5438-5446.

Goslin, K. and G. Banker. 1991. Rat hippocampal neurons in low-density culture. In Culturing nerve cells led. G. Banker and K. Goslin), pp. 251-282. MIT Press, Cambridge, MA.

Grant, S.G.N., T.J. O’Dell, K.A. Karl, P.L. Stein, P. Soriano, and E.R. Kandel. 1992. Impaired long-term potentiation, spatial learning, and hippocampal development in fyn mutant mice. Science 258: 1903-1910.

Guan, J.-L. and D. Shalloway. 1992. Regulation of focal adhesion associated protein tyrosine kinase by both cellular adhesion and oncogenic transformation. Nature 358: 690-692.

Gutkind, J.S. and K.C. Robbins. 1992. Activation of transforming $\mathrm{G}$ protein-coupled receptors induces tyrosine phosphorylation of cellular proteins, including $\mathrm{pp} 125^{\mathrm{FAK}}$ and the pl30 v-src substrate. Biochem. Biophys. Res. Commun. 188: 155-161.

Hamawy, M.M., S.E. Mergenhagen, and R.P. Siraganian. 1993. Tyrosine phosphorylation of $\mathrm{pp} 125^{\mathrm{FAK}}$ by the aggregation of high affinity immunogloubin $\mathrm{E}$ receptors requires cell adherence. J. Biol. Chem. 268: 6851-6854.

Hanks, S.K, M.B. Calalb, M.C. Harper, and S.K. Patel. 1992. Focal adhesion protein tyrosine kinase phosphorylated in response to cell attachment to fibronectin. Proc. Natl. Acad. Sci. 89: 8487-8491.

Harlow, E. and D. Lane. 1988. Antibodies: A laboratory manual. Cold Spring Harbor Laboratory, Cold Spring Harbor, New York.

Hatai, M., H. Hashi, A. Mogi, H. Soga, J. Yokota, and Y. Yaoi. 1994. Stimulation of tyrosine- and serine-phosphorylation of focal adhesion kinase in mouse 3T3 cells by fibronectin and fibroblast growth factor. FEBS Lett. 350: 113-116.

Hildebrand, J.D., M.D. Schaller, and J.T. Parsons. 1993. Identification of sequences required for the efficient localization of the Focal Adhesion Kinase, pp $125^{\mathrm{FAK}}$, to cellular focal adhesions. I. Cell. Biol. 123: 993-1005.

Huang, X.-Y., A.D. Morielli, and E.G. Peralta. 1993. Tyrosine kinase-dependent suppression of a potassium channel by the $\mathrm{G}$ protein-coupled $\mathrm{ml}$ muscarinic acetylcholine receptor. Cell 75: 1145-1156.

Hummler, E., T.J. Cole, J.A. Blendy, R. Ganss, A. Aguzzi, W. Schmid, F. Beerman, and G. Schutz. 1994. Targeted mutation of the CREB gene: Compensation within the CREB/ ATF family of transcription factors. Proc. Natl. Acad. Sci. 91: 5647-5651.

Hynes, R.O. 1992. Integrins: Versatility, modulation, and signaling in cell adhesion. Cell 69: 11-25.

Kanner, S.B., A.B. Reynolds, R.R. Vines, and J.T. Parsons. 1990. Monoclonal antibodies to individual tyrosine-phosphorylated protein substrates of oncogene-encoded tyrosine kinases. Proc. Natl. Acad. Sci. 87: 3328-3332.

Kaplan, M.P., S.S.M. Chin, P. Macioce, J. Srinawasan, G. Hashim, R.K.H. Liem. 1991. Characterization of a panel of neurofilament antibodies recognizing $\mathrm{N}$-terminal epitopes. J. Neurosci. Res. 30: 545-554.

Kornberg, L., H.S. Earp, J.T. Parsons, M. Schaller, and R.L. Juliano. 1992. Cell adhesion or integrin clustering increases phosphorylation of a focal adhesion-associated tyrosine kinase. I. Biol. Chem. 267: 23439-23442.

Kypta, R.M., Y. Goldberg, E.T. Uleg, and S.A. Courtneidge. 1990. Association between the PDGF receptor and members of the Src family of tyrosine kinases. Cell 62: 481-492.

Laemmli, U.K. 1970. Cleavage of structural proteins during the assembly of the head of bacteriophage T4. Nature 227: 680685.

Levison, S.W. and K.D. McCarthy. 1991. Astroglia in culture. In Culturing nerve cells (ed. G. Banker and G. Goslin), pp. 309336. MIT Press, Cambridge, MA.

Levy, J.B., T. Dorai, L.-H. Wang, and J.S. Brugge. 1987. The structurally distinct form of $\mathrm{pp} 60^{\mathrm{c}-\mathrm{src}}$ detected in neuronal cells is encoded by a unique c-src mRNA. Mol. Cell. Biol. 7: 4142-4145.

Linstedt, A.D., M.L. Vetter, J.M. Bishop, and R.B. Kelly. 1992. Specific association of the proto-oncogene product $\mathrm{pp} 60^{\mathrm{c}-\mathrm{src}}$ with an intracellular organelle, the PC12 synaptic vesicle. $J$. Cell. Biol. 117: 1077-1084.

Lipfert, L., B. Haimovich, M.D. Schaller, B.S. Cobb, J.T. Parsons, and J.S. Brugge. 1992. Integrin-dependent phosphorylation and activation of the protein tyrosine kinase pp125 12 in platelets. I. Cell. Biol. 119: 905-912.

Lowell, C.A., P. Soriano, and H.E. Varmus. 1994. Functional overlap in the Src-gene family: Inactivation of hck and fgr impairs natural immunity. Genes \& Dev. 8: 387-398.

Malenka, R.C., J.A. Kauer, D.J. Perkel, M.D. Mauk, P.T. Kelly, R.A. Nicoll, and M.N. Waxham. 1989. An essential role for postsynaptic calmodulin and protein kinase activity in longterm potentiation. Nature 349: 554-557.

Malinow, R., H. Schulman, and R.W. Tsien. 1989. Inhibition of postsynaptic PKC or CamKII blocks induction but not expression of LTP. Science 245: 862-866.

Maness, P.F. 1992. Non-receptor protein tyrosine kinases associated with neuronal development. Dev. Neurosci. 14: 257270.

Maness, P.F., M. Aubrey, C.G. Shores, L. Frome, and K.H. Pfenninger. 1988. c-src gene product in developing rat brain is enriched in nerve growth cone membranes. Proc. Natl. Acad. Sci. 85: 5001-5005.

O'Dell, T.J., E.R. Kandel, and S.G.N. Grant. 1991. Long-term potentiation in the hippocampus is blocked by tyrosine kinase inhibitors. Nature 353: 558-560.

Parsons, J.T. and M.J. Weber. 1989. Genetics of Src: Structure and functional organization of a protein tyrosine kinase. Curr. Top. Microbiol. Immunol. 147: 79-127.

Pawson, T. 1995. Protein modules and signalling networks. $\mathrm{Na}$ ture 373: 573-580.

Polte, T.R., A.J. Naftilan, and S.K. Hanks. 1994. Focal adhesion kinase is abundent in developing blood vessels and elevation if its phosphotyrosine content in vascular smooth muscle cells is a rapid response to angiotensin II. J. Cell. Biochem. 55: 106-119.

Pyper, J.M. and J.B. Bolen. 1990. Identification of a novel neuronal c-src exon expressed in human brain. Mol. Cell. Biol. 10: 2035-2040.

Rosahl, T.W., M. Geppert, D. Spillane, J. Herz, R.E. Hammer, R.C. Malenka, and T.C. Sudhof. 1993. Short-term synaptic plasticity is altered in mice lacking synapsin I. Cell 75: 661670.

Rudd, C.E., O. Janssen, K.V.S. Prasad, M. Raab, A. da Silva, J.C. 
Telfer, and M. Yamamoto. 1993. Src-related protein tyrosine kinases and their surface receptors. Biochim. Biophys. Acta 1155: 239-266.

Rudnicki, M.A., T. Braun, S. Hinuma, and R. Jaenisch. 1992. Inactivation of $\mathrm{MyoD}$ in mice leads to up-regulation of the myogenic gene Myf- 5 and results in apparently normal muscle development. Cell 71: 383-390.

Sakimura K., T. Kutsuwada, I. Ito, T. Manabe, C. Takayama, E. Kushiya, T. Yagi, S. Aizawa, Y. Inoue, H. Sugiyama, and $M$. Mishina. 1995. Reduced hippocampal LTP and spatial learning in mice lacking NMDA receptor epsilon 1 subunit. $\mathrm{Na}$ ture 373: 151-155.

Schaller, M.D., C.A. Borgman, B.S. Cobb, R.V. Vines, A.B. Reynolds, and J.T. Parsons. 1992. pp $125^{\mathrm{FAK}}$, a structurally distinctive proein tyrosine kinase associated with focal adhesions. Proc. Natl. Acad. Sci. 89: 5192-5196.

Schaller, M.D., C.A. Borgman, and J.T. Parsons. 1993. Autonomous expression of a noncatalytic domain of the focal adhesion-associated protein tyrosine kinase pp $125^{\mathrm{FAK}}$. Mol. Cell. Biol. 13: 785-791.

Schaller, M.D., J.D. Hildebrand, J.D. Shannon, J.W. Fox, R.R. Vines, and J.T. Parsons. 1994. Autophosphorylation of the focal adhesion kinase, ppl25 $5^{\mathrm{FAK}}$, directs SH2-dependent binding of pp60 ${ }^{\text {src }}$. Mol. Cell. Biol. 14: 1680-1688.

Shattil, S.J., B. Haimovich, M. Cunninghan, L. Lipfert, J.T. Parsons, M.H. Ginsberg, and J.S. Brugge. 1994. Tyrosine phosphorylation of ppl25 12 in platelets requires coordinated signaling through integrin and agonist receptors. J. Biol. Chem. 26: 14738-14745.

Schlaepfer, D.D., S.K. Hanks, T. Hunter, and P. van der Greer. 1994. Integrin-mediated signal transduction linked to Ras pathway by GRB2 binding to focal adhesion kinase. Nature 372: 786-791.

Silva, A.J., C.F. Stevens, S. Tonegawa, and Y. Wang. 1992a. Deficient hippocampal long-term potentiation in alpha-calcium-calmodulin kinase II mutant mice. Science 257: 201206.

Silva, A.J., R. Paylor, J.M. Wehner, and S. Tonegawa. 1992b. Impaired spatial learning in alpha-calcium-calmodulin kinase II mutant mice. Science 257: 206-211.

Sinnett-Smith, J., I. Zachary, A.M. Valverde, and E. Rozengurt. 1993. Bombesin stimulation of pl25 focal adhesion kinase tyrosine phosphorylation. I. Biol. Chem. 268: 14261-14268.

Sobue, K. and K. Kanda. 1988. Localization of pp60 $0^{\mathrm{c}-\mathrm{src}}$ in growth cone of PC12 cells. Biochim. Biophys. Res. Commun. 157: 1383-1389.

Stein, P.L., H.-M. Lee, S. Rich, and P. Soriano. 1992. pp59fyn mutant mice display differential signaling in thymocytes and peripheral cells. Cell 70: 741-750.

Stein, P.L., H. Vogel, and P. Soriano. 1994. Combined deficiences of Src, Fyn and Yes tyrosine kinase mutant mice. Genes \& Dev. 8: 1999-2007.

Sudol, M., S.G.N. Grant, and P.C. Maisonpierre. 1993. Protooncogenes and signaling processes in neural tissues. Neurochem. Int. 22: 369-384.

Tawil, N., P. Wilson, and S. Carbonetto. 1993. Integrins in point contact mediate cell spreading: Factors that regulate integrin accumulation in point contacts versus focal contacts. $J$. Cell. Biol. 120: 261-271.

Umemori, H., A. Wanaka, H. Kato, M. Takeuchi, M. Tohyama, and T. Yamamoto. 1992. Specific expression of Fyn and Lyn, lymphocyte antigen receptor-associated tyrosine kinase, in the central nervous system. Mol. Brain Res. 16: 303-310.

Umemori H., S. Sato, T. Yagi, S. Aizawa, and T. Yamamoto. 1994. Initial events of myelination involve Fyn tyrosine ki- nase signalling. Nature 367: 572-576.

Vuori, K. and E. Rhuoslahti. 1993. Activation of protein kinase $\mathrm{C}$ precedes a5bl integrin-mediated cell spreading on $\mathrm{fi}$ bronectin. I. Biol. Chem. 68: 21459-21462.

Wallace, C.S., N. Hawrylak, and W.T. Greenough. 1991. Studies of synaptic structural modifications after long-term potentiation and kindling: Context for a molecular morphology. In Long-term potentiation: A debate of current issues (ed. M. Baudry, J.L. Davis), pp 189-232. MIT Press, Cambridge, MA.

Wang, E., J.G. Cairncross, and R.K.H. Liem. 1984. Identification of glial filament proteins and vimentin in the same intermediate filament system in human glioma cells. Proc. Natl. Acad. Sci. 81: 2102-2106.

Wu, Z.L., S.A. Thomas, E.C. Villacres, Z. Xia, M.L. Simmons, C. Chavkin, R.D. Palmiter, and D.R. Storm. 1995. Altered behavior and long-term potentiation in type I adenylyl cyclase mutant mice. Proc. Natl. Acad. Sci. 92: 220-224.

Xing, Z., H.C. Chen, J.K. Nowlen, S.J. Taylor, D. Shalloway, and J.L. Guan. 1994. Direct interaction of v-Src with the focal adhesion kinase mediated by the Src SH2 domain. Mol. Biol. Cell 5: 413-421.

Zachary, I., J. Sinnett-Smith, and E. Rozengurt. 1992. Bombesin, vasopressin, and endothelin stimulation of tyrosine-phosphorylation in swiss 3 T3 cells. I. Biol. Chem. 267: 1903119034. 


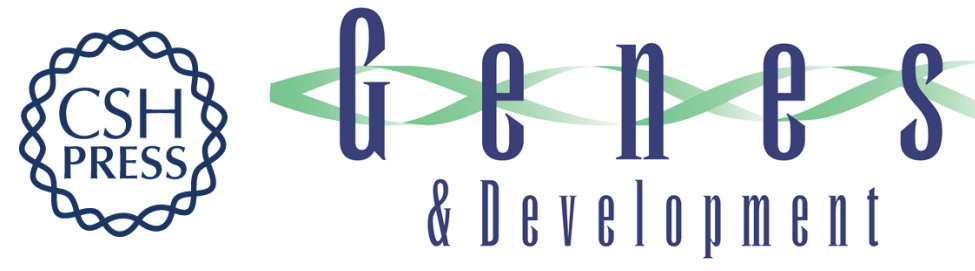

\section{Focal adhesion kinase in the brain: novel subcellular localization and specific regulation by Fyn tyrosine kinase in mutant mice.}

S G Grant, K A Karl, M A Kiebler, et al.

Genes Dev. 1995, 9:

Access the most recent version at doi:10.1101/gad.9.15.1909

References This article cites 83 articles, 36 of which can be accessed free at:

http://genesdev.cshlp.org/content/9/15/1909.full.html\#ref-list-1

License

Email Alerting

Service

Receive free email alerts when new articles cite this article - sign up in the box at the top right corner of the article or click here.

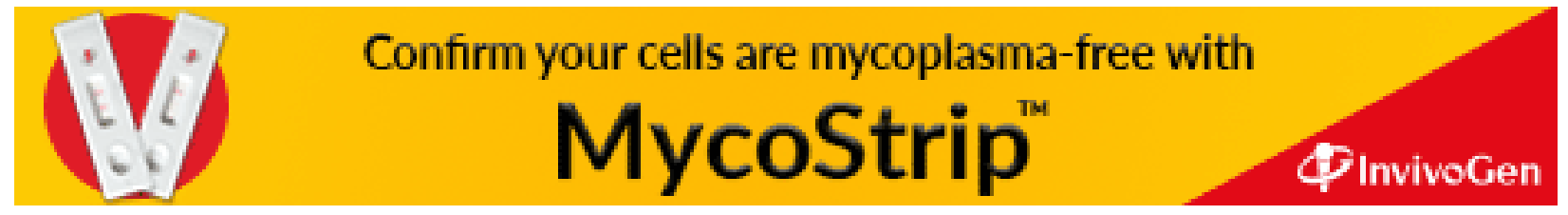

